\title{
O grande jogo do casamento: \\ um desafio antropológico \\ e computacional em área \\ de fronteira
}

DoI

http://dx.doi.org/10.11606/ 2179-0892.ra.2017.137313

\section{Marcio Silva}

- Universidade de São Paulo / São Paulo, SP, Brasil

-marciofs@usp.br

\section{RESUMO}

Para Schneider, os estudos antropológicos de parentesco estão ancorados em uma Doutrina da Unidade Cenealógica da Humanidade que teria distorcido a percepção etnográfica e consagrado um "non-subject". Esta Doutrina pode ser assim resumida: em todas as culturas humanas, parentesco tem a ver com o reconhecimento de vínculos naturais entre os indivíduos, assim afiançando sua tradução universal em termos genealógicos. Este artigo se contrapõe à crítica de Schneider em duas frentes: indaga se necessariamente convém entender o método genealógico como um dispositivo de tradução; em outra, questiona se o método genealógico requer tal Doutrina para se definir. Paralelamente, a partir da pesquisa etnográfica concernente aos Enawene-Nawe, este artigo, nos horizontes da teoria da aliança, argumenta em favor da reabilitação do método genealógico que, neste século, não pode abrir mão de ferramentas computacionais. Isto, considerando que "a primeira tarefa da antropologia, pré-requisito de todas as outras, é entender e formular os símbolos e sentidos e suas configurações, de que uma cultura particular consiste" (ênfase no original, Schneider, 1984: 196).

\section{Palavras-chave}

Parentesco, genealogia, tradução e modelo, teoria da aliança, EnaweneNawe. 


\section{INTRODUÇÃO'}

Ao longo do período de emergência e consolidação das matrizes teóricas clássicas da disciplina, os estudos de parentesco desempenharam um papel fundamental, acumulando "uma vasta bibliografia que abrange, talvez, mais da metade do total da literatura antropológica" (Fox, 1967: 10) produzida até meados do século XX. Como Holy (1996: 1) chama a atenção, nos primeiros cem anos da disciplina, são raros os antropólogos com alguma projeção que não contribuíram, de alguma forma, para o desenvolvimento dos estudos de parentesco. Mas, quis a história que seus expoentes quase nunca estivessem de acordo sobre as formas de lidar com o tema. Ao contrário, controvérsias, mais ou menos ácidas, desde sempre figuram em primeiro plano, como não desmentem as disputas sobre as origens da família e sobre o sentido dos sistemas classificatórios, que inauguram os estudos de parentesco e, por eles, a antropologia social, na segunda metade do Século XIX. Parodiando uma fórmula sobre as diferenças entre os irmãos sol e lua nos mitos ameríndios, não seria exagero dizer que, desde então, essas e outras controvérsias foram amplificadas, multiplicadas e dispostas em perpétuo desequilíbrio. Um balanço dos Kinship Studies no fim do milênio, publicado em um volume especial da revista L'Homme, não deixa dúvidas de que as querelas e questões de parentesco continuam na ordem do dia, transpondo as fronteiras temáticas clássicas em todas as direções (Collard, 2000: 635-58). Neste mesmo volume, Lévi-Strauss, em um de seus últimos textos, regozija-se com a riqueza e a diversidade de seus horizontes e conclui que "os problemas do parentesco e da aliança continuam no primeiro plano das preocupações dos etnólogos" (2000: 713).

Os estudos de parentesco lembram um vulcão antigo, em intensa atividade desde as primeiras erupções. Por esta razão, não deixa de ser curioso que um dos autores cujas ideias mais produziram fluxos piroclásticos, nas últimas décadas, tenha sido precisamente aquele que decretou sua extinção. Em uma obra de extraordinário impacto, Schneider (1984) argumenta que parentesco é uma noção etnocêntrica, um senso comum do Ocidente, blindado com foro privilegiado por uma legião de autores, cuja lista é um Who is Who da antropologia. Tal blindagem teria afiançado uma relação de dependência entre parentesco e genealogia, apoiada em um pressuposto enganoso: o de que o parentesco, em todas as culturas humanas, tem por missão representar, refletir, simbolizar, organizar, etc. relações naturais entre os indivíduos. A tradução genealógica universal teria assim produzido um falso denominador comum pelo qual fenômenos incomensuráveis passaram a ser especiosamente tomados como sistemas de parentesco. Parentesco, em suma, seria mais um non-subject da disciplina, uma ilusão como o totemismo e o matriarcado. Lastreado em uma Doutrina da Unidade Cenealógica
1 Uma versão oral deste texto foi apresentada como aula no concurso para professor titular de Antropologia Social, na Faculdade de Filosofia, Letras e Ciências Humanas, da Universidade de São Paulo, em 28 de janeiro de 2016 . Agradeço aos colegas do CEstA, Stelio Marras (IEB-USP) e Renato Sztutman (FFLCHUSP) e a Adriana Queiroz Testa (UFCH-UNICAMP) a leitura atenta das notas de aula e os comentários, que me convenceram a produzir este manuscrito. A consolidação dos dados genealógicos enawenenawe e a construção do primeiro software empregado em seu estudo receberam o generoso apoio da FAPESP (AP 08/53352-3). Alguns argumentos aqui defendidos nasceram de diálogos com João Dal Poz (UFJF), sócio na construção da ferramenta computacional, com Miriam Hartung (UFSC), que também enfrenta os desafios do tratamento informático do parentesco, e com Carlos Eduardo Ferreira (IME-USP), parceiro no CEstA. 
da Humanidade, o conceito foi desde sempre um eterno refém da biologia, o que acarretou péssimas traduções (traições) dos "símbolos e sentidos e suas configurações de que uma cultura particular consiste" (1984: 196). A crítica de Schneider não poupa ninguém do panteão do parentesco, nem mesmo ele próprio. Ao contrário. Sua famosa análise do tabinau em Yap é a primeira a ir para o paredão.

As provocações do autor, que retomam teses ensaiadas anteriormente (Schneider, 1972) tiveram repercussão imediata. Mas as frases de efeito de seu texto, tão características de seu estilo, foram às vezes mal interpretadas. A própria afirmação bombástica de que parentesco é um non-subject, que não existe em lugar nenhum a não ser na cabeça dos antropólogos, foi, por muitos, tomada como voz de comando de ordem unida: os estudos de parentesco deveriam bater em retirada do teatro de operações da antropologia. Os prejuízos deste mal-entendido não tardaram a se manifestar nos batalhões da disciplina.

Ora, "Parentesco é um non-subject" não é ordem unida, nem atestado de óbito dos estudos de parentesco. É uma contribuição válida a uma reflexão centenária, como tantas outras do autor. Como tal, não ficou sem réplica. Tendo enviado a Lévi-Strauss uma cópia de sua comunicação "What is kinship all about?", apresentada em um evento que celebrou os cem anos da publicação dos Sistemas de consanguinidade e afinidade da família humana, Schneider recebe essas breves linhas de agradecimento, escritas em inglês, reproduzidas por McKinley (2001: 144):

Muito obrigado por me mandar What is kinship all about?'. Embora eu concorde com você em muitos pontos, não iria tão longe em dizer que parentesco é um "non-subject". Eu o definiria como um modo de classificar pessoas e definir seus direitos e obrigações de acordo com casamentos passados e com previsão de futuros. Esta formulação é muito desajeitada porque nada é mais difícil que frasear uma definição em uma língua estrangeira, mas estou certo de que você vai captar meu ponto, que é o de que parentesco tem a ver com casamento eque proibições, prescrições e preferências matrimoniais não são um non-subject. Claude Lévi-Strauss, 10 de fevereiro de 1971.

Os argumentos que submeto a seguir vão nesta mesma direção. São eles: o conceito de parentesco não depende da pressuposição de uma Doutrina da Unidade Cenealógica da Humanidade para se definir e o método genealógico, inventado por Rivers no Estreito de Torres, em 1898, continua sendo uma boa ferramenta de acesso aos símbolos e sentidos e suas configurações de que uma cultura particular consiste, desde que não o tomemos como um Google translator toolkit, mas como um artifício de modelagem. 


\section{TRADUÇÃO E MODELO}

Minha ressalva à tese de Schneider pode ser assim resumida: antes de tudo, devemos nos perguntar se o que o método genealógico produz são necessariamente traduções do parentesco. Boas ou péssimas, não faz diferença. Lições muito conhecidas da linguística estrutural nos ensinam que é possível entender o método genealógico de outra maneira.

Como Jakobson ([1959] 1995: 64) chama a atenção, "para o linguista como para o usuário comum das palavras, o significado de um signo linguístico não é mais que a sua tradução por outro signo que lhe pode ser substituído". Tal substituição pode se efetuar no interior de um mesmo código, quando se diz, por exemplo, "lousa quer dizer quadro-negro" ou entre códigos linguísticos distintos, quando se diz "cat quer dizer gato". Para o autor, este mesmo processo de substituição pode operar também entre códigos semióticos distintos. Assim, por exemplo, uma narrativa oral pagã russa, A sagração da primavera, foi traduzida por Botticelli em signos pictóricos, por Stravinsky em signos musicais, e por Pina Bausch, em signos coreográficos (Figura 1).
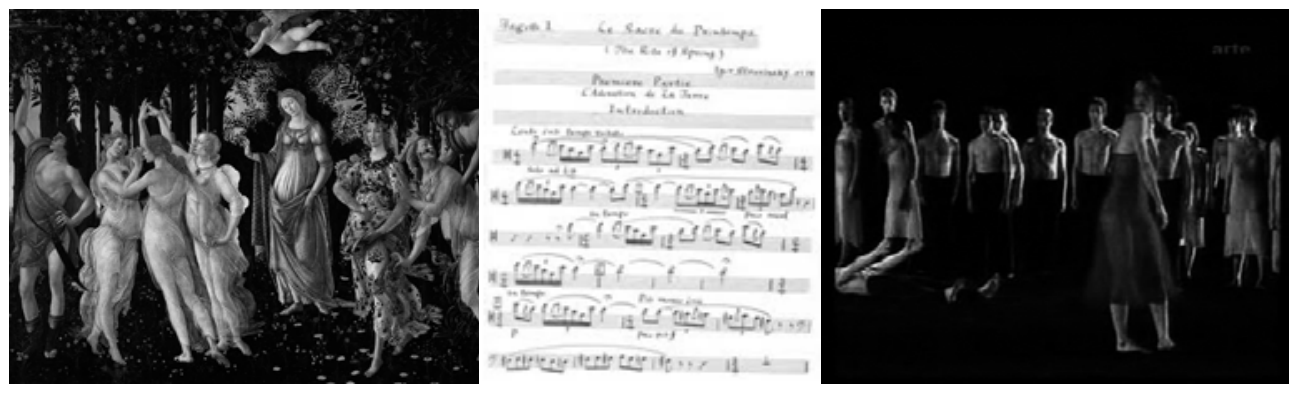

Figura 1

Traduções de Botticelli, Stravinsky e Pina Bausch de uma narrativa mítica.

Para Jakobson, os diferentes tipos de tradução são modalidades de uma mesma operação de substituição de signos, que estabelece relações de sentido entre o que é substituído e o que o substitui. Em outro texto, retomando as teses de Saussure e Pierce, o autor lembra que todo signo implica dois modos de arranjo, seleção e combinação. Uma "seleção entre termos implica a possibilidade de substituição de um por outro, equivalente ao primeiro num aspecto e diferente em outro". Enquanto isso, uma combinação implica um contexto, uma vez que "qualquer unidade linguística serve, ao mesmo tempo, de contexto para unidades mais simples e/ou encontra seu próprio contexto em uma unidade linguística mais complexa" ([1956] 1995: 39-40). Os atos de fala são presididos por essas duas operações simultâneas. A primeira, seleção / substituição, define relações in absentia, enquanto a segunda, combinação / contextura, está voltada às relações in praesentia. Com base nessas operações, Jakobson estabelece o sentido moderno de duas figuras da retórica clássi- 
ca: "o mais acertado seria talvez falar de processo metafórico no primeiro caso, e de processo metonímico no segundo, de vez que eles encontram sua expressão mais condensada na metáfora e na metonímia respectivamente" ([1956] 1995: 55).

A distinção consagrada por Jakobson permite em tese entender "genealogia" de duas maneiras que não se confundem: como metáfora ou metonímia de uma rede de relações de parentesco. No primeiro caso, estamos diante de uma tentativa de tradução de seu sentido, no segundo, de um exercício de modelagem de algumas de suas propriedades ${ }^{2}$. Analogamente, um enunciado pode ser traduzido por outro, se estamos interessados em determinar seu significado, ou modelado, se desejamos isolar algumas propriedades e relações nele observadas, como acontece, por exemplo, em uma transcrição fonética. Neste caso, o sentido do enunciado não está em questão, mas apenas um conjunto de qualidades articulatórias ou acústicas envolvidas em sua produção, que define uma cadeia de elementos discretos. Esta cadeia estabelece relações in praesentia com um continuum sonoro, como na Figura 2.

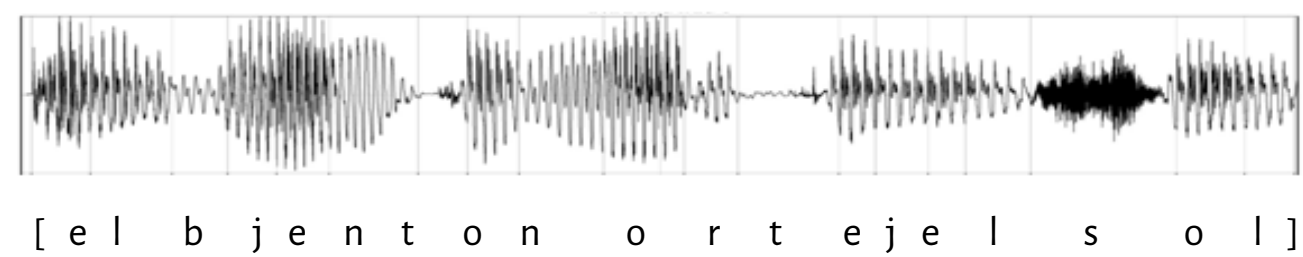

A distinção de Jakobson nos autorizaria a dar mais um passo. A genealogia enawene-nawe e o célebre retrato de Clouet, reproduzido por Lévi-Strauss (1962) em O pensamento selvagem, são objetos que guardam entre si uma semelhança e uma diferença importantes. Semelhança, porque que ambos são modelos (reduzidos, por definição). Diferença, porque se situam em lados opostos da distinção de Jakobson, um deles, no polo metonímico, e outro no polo metafórico. Evocando o paralelismo consagrado por Lévi-Strauss, podemos dizer que um deles é obra de engenharia, e o outro, de bricolagem.
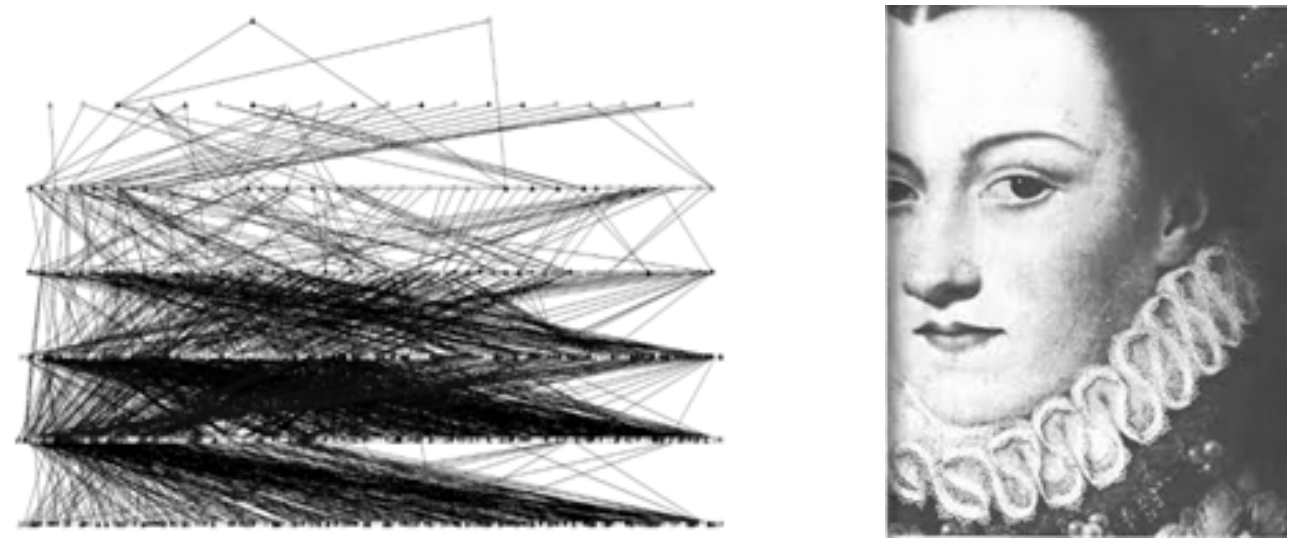

2 Aos interessados no tema da relação genealogia e antropologia, recomendo a leitura de Porqueres i Cené (2008).

\section{Figura 2}

Continuum sonoro e modelagem do enunciado espanhol "El viento norte y el sol".

\section{Figura 3}

Dois modelos reduzidos: a genealogia enawene-nawe e o retrato de Clouet. 
Recordemos, muito resumidamente, o que Lévi-Strauss nos diz daquele retrato. Clouet "gostava depintar em proporções menores que asda natureza; seusquadros são, portanto, como osjardins japoneses, os carros emminiatura e os barcos dentro degarrafas o que, em linguagem de bricoleur,denomina-se 'modelos reduzidos". A arte "implica sempre a renúncia a certas dimensões do objeto" e o prazer estético que proporciona parece resultado da inversão do processo cotidiano do conhecimento. Diz o autor, "no modelo reduzido, o conhecimento do todo precede o das partes". Mas não só isso. Lévi-Strauss chama também atenção de que um modelo tem uma qualidade suplementar: "é construído, man made, e mais que isso, 'feito à mão", não sendo, "portanto, uma simples projeção, um homólogo passivo do objeto: constitui uma verdadeira experiência sobre o objeto". $\mathrm{O}$ autor prossegue: "na medida em que o modelo é artificial, torna-se possível compreender como ele é feito". Precisamente por isso, o problema do artista, assim como o do bricoleur, "sempre comporta várias soluções" ou, retomando os termos da linguística estrutural, implica em todos os casos relações in absentia. E acrescenta: "Comoa escolha de uma solução acarreta uma modificação doresultado a que uma outra solução teria conduzido, o que está virtualmente dado é o quadro geral dessas permutas, aomesmo tempo que a solução específica oferecida aoolhar doespectador, dessa maneira - mesmo sem o saber - transformado em agente" (Lévi-Strauss, [1962] 2008: 38-40).

Assim, o prazer estético decorreria, entre outras coisas, da percepção das relações in absentia implicadas na seleção do artista. Precisamente por isso, podemos entender o retrato de Clouet como uma redução metafórica do objeto. Ou, nos termos de Jakobson, a uma modalidade de tradução. Mas o que poderia resultar se, diante de um dado objeto, procedêssemos não sua redução metafórica, à moda do bricoleur, mas a sua redução metonímica, à moda do engenheiro? Lévi-Strauss não deixa de sugerir a possibilidade desse outro procedimento ao contrastar os métodos da ciência e da arte, exatamente como Jakobson o faria. "O primeiro procedimento é da ordem da metonímia...ao passo que o segundo é da ordem da metáfora" ([1962] 2008: 40).

Assim, com propósitos e métodos muito diferentes daqueles de um bricoleur ou de um artista, os engenheiros também produzem modelos reduzidos quando estão, por exemplo, envolvidos na construção de um novo avião, que deve voar em altas altitudes e enfrentar condições atmosféricas extremas. Diante de um desafio tão complexo, um método é acionado a fim de assegurar a redução de sua complexidade, de modo a tornar possível a abordagem do problema. Observemos mais de perto este outro tipo de experiência sobre o objeto.

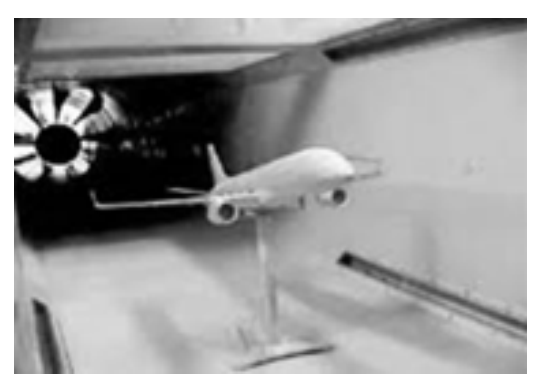

Figura 3

Modelo reduzido de um avião em um túnel de vento. 
Bem antes de o novo avião existir, os engenheiros constroem um modelo do avião para estudar sua resistência ao ar. Este modelo consiste em uma miniatura que guarda apenas duas qualidades do futuro avião, as proporções de sua superfície e a resistência de seus materiais. Neste aviãozinho (Figura 4), são ignorados comandos, motores, janelas, poltronas, cintos de segurança, etc., e tantas outras coisas que não podem faltar em um "avião de verdade", mas que, neste momento, são irrelevantes. Uma vez modelado, o aviãozinho é inserido em um túnel de vento, que também é uma miniatura das condições do espaço aéreo na velocidade que o "avião de verdade" voará. Com o uso de possantes ventiladores, os engenheiros dirigem o fluxo de ar contra o aviãozinho e estudam sua interação com as diferentes superfícies do modelo que, supõe-se, são idênticas às que o "avião de verdade" vai enfrentar. Ora, a modelagem genealógica de uma rede de parentesco corresponde a um objeto do mesmo tipo. Como podemos fabricá-la?

Partimos da premissa de que não há como presumir a existência de uma rede de relações, que possa ter algum interesse para a antropologia, que seja anterior àquelas definidas por uma dada cultura. São estas, portanto, as matérias-primas de qualquer modelagem antropológica. Assim, diante de uma rede empírica de parentesco, se há interesse em estudar suas dinâmicas, é possível elaborar um modelo reduzido desta rede, levando-se em conta apenas algumas de suas qualidades, como por exemplo, a diferença sexual entre seus nós e a presença ou ausência de orientação de suas linhas, que definem dois tipos de vínculos entre os nós da rede, filiação e casamento, definidos em intervalos temporais. Particularmente, na rede enawene-nawe explorada neste artigo, podemos, além disso, incluir informações sobre os nove clãs existentes e foi o que fizemos. Poderíamos levar em conta também parâmetros como residência, metades, paróquias, relações com não humanos e assim por diante, ou não levar em conta, por exemplo, parâmetros como a distinção sexual. Tudo vai depender dos propósitos do estudo que se quer fazer. A seleção dos parâmetros é parte da análise e, como Borges Neto (2004: 20) aponta, qualquer seleção é arbitrária (no sentido de que deve ser arbitrada pelo analista) uma vez que não é a própria realidade que diz como quer ou deve ser abordada, mas já resultado de escolhas, premissas, crenças, preferências, etc., que cada observador traz consigo. Exatamente como o aviãozinho no túnel de vento sem instrumentos de comando, luzes de sinalização, etc., uma grande quantidade de aspectos importantíssimos de uma rede empírica de relações de parentesco deve ser subtraída em sua modelagem, a fim de favorecer sua abordagem, com um dado propósito. A única condição do método é que as qualidades selecionadas na elaboração do modelo estabeleçam relações in praesentia com o objeto no mundo. Este procedimento é o que permite transformar em objeto teórico um dado fenômeno do mundo que se pretende conhecer. 
Isto nos conduz a outro ângulo do desafio. Em um texto sobre o lugar e o ensino da antropologia, Lévi-Strauss ([1954] 2003: 403-4) chama a atenção de que sociologia e antropologia são ciências sociais diferentes quanto ao ponto de vista que elaboram em relação a seus objetos. No esforço do sociólogo

para extrair interpretações e significações (...) são suas próprias categorias lógicas, suas próprias perspectivas históricas, que aplica ao conjunto. [Enquanto isso,] o antropólogo, colocado diante da mesma tarefa, esforçar-se-á, voluntária e conscientemente também (e de modo algum está certo de que um dia tenha sucesso), em formular um sistema aceitável, tanto para o mais longínquo indígena como para seus próprios concidadãos ou contemporâneos.

E o autor acrescenta, "Enquanto a sociologia se esforça em fazer a ciência social do observador, a antropologia procura, por sua vez, elaborar a ciência social do observado". Em suma, caberia ao observado, e não ao observador, oferecer os parâmetros de uma modelagem genealógica propriamente antropológica. Até porque, nunca é demais lembrar, "um sistema de parentesco (...) só existe na consciência dos homens; é um sistema arbitrário de representações" (Lévi-Strauss, [1945] 2003: 69). Posto isso, como se pode conceber uma genealogia do observado?

\section{UMA GENEALOGIA DO OBSERVADO}

Como as possibilidades de abordagem de qualquer fenômeno são incontáveis, não vale a pena enfrentar o problema abstratamente. No lugar disso, consideremos um caso etnográfico particular. Os Enawene-Nawe, povo indígena de língua aruak, vivem em um território situado no vale do Rio Juruena, um dos formadores do Rio Tapajós, na Amazônia meridional brasileira (Silva, 1998, 2013). Em 31 de julho de 2011 , a população era de 610 indivíduos. Até esta data, a pesquisa genealógica registrou a memória de 179 mortos. O emprego intensivo do método de Rivers (1910) permitiu a integração de vivos e falecidos em uma única rede, com as seguintes características gerais: 391 homens, 398 mulheres, 1.368 relações de filiação e 170 matrimônios, envolvendo 159 homens e 165 mulheres, distribuídos em nove clãs patrilineares (yãkwa). Ao longo da vida, a imensa maioria das pessoas se casa uma única vez. Na genealogia em questão, 76 pessoas não têm pai. São ditos "filhos de enawene [genérico]" (enawene hetaĩ), e, neste caso, pertencem ao clã da mãe ou, para ser exato, ao do pai da mãe. É possível determinar os quatro avós de 546 indivíduos, a mãe de 722 e o pai de 646.

Esta rede tem profundidade genealógica máxima (cadeia linear vertical mais longa) de seis gerações, e média de três. Do ponto de vista matrimonial, 
os Enawene-Nawe constituem um isolado demográfico, formando um coletivo estritamente endogâmico. Este povo opera uma terminologia iroquesa (Murdock, 1949; Lounsbury, 1964) que distingue, nas três gerações mediais, parentes consanguíneos colaterais paralelos e cruzados (como, por exemplo, tio paterno e tio materno, filho(a) de germano de mesmo sexo e filho(a) de germano de sexo oposto) e, em contrapartida, cobre com um único termo parentes consanguíneos lineares e colaterais paralelos (como, por exemplo, pai e tio paterno, filho(a) e filho(a) de germano de mesmo sexo). Esta estrutura conceitual opera associada a um subsistema de tecnônimos exclusivamente voltado aos afins (sogro = "avô do filho", nora = "mãe de neto", cunhado = "tio de filho" e assim por diante). Para Héritier (1981: 74-7), o método iroquês pode ser correlato terminológico de um sistema semicomplexo.

Não obstante, o discurso nativo define o regime de aliança enawene-nawe como uma estrutura complexa (Lévi-Strauss, [1949] 1967), que não formula regra positiva (prescritiva) de casamento, mas apenas algumas proibições. São proscritas as uniões entre pessoas do mesmo clã e entre consanguíneos genealogicamente próximos (como tios, sobrinhos, primos de primeiro grau, etc.) ainda que de clãs distintos. Por outro lado, os Enawene-Nawe apontam o intercâmbio matrimonial de pares de filhos de sexo oposto, entre duas famílias, característico das estruturas elementares de parentesco, como a fórmula virtuosa de união matrimonial (Silva, 2012), para a qual consagram uma expressão nativa (emamanenase). $O$ que não se pode fazer é repetir a fórmula na geração seguinte, envolvendo as mesmas famílias parceiras, pois seus filhos serão primos entre si.

Entre os Enawene-Nawe, a relação entre as categorias nativas de parentesco e as redes genealógicas é refratada por normas, condutas, modelos sobre vínculos reprodutivos e esquemas de nominação. A língua falada pelos Enawene-Nawe não dispõe de termos que sejam correspondentes semânticos perfeitos das noções de "F", "M", "S", "D", "H" e "W", definidas pelo método genealógico. É verdade que os vocábulos "hahare" e "mamalo" cobrem, respectivamente, o significado de "F" e "M", e o mesmo pode ser dito do vocábulo "etaî", em relação a "S" e "D", e do par "nerani" e "neranetõ", em relação a "H" e "W". Mas esses termos também cobrem muitas outras posições genealógicas. Assim, por exemplo, "hahare" quer dizer F, mas também FB, FFBS, etc. O mesmo pode ser dito em relação aos termos que designam " $\mathrm{H}$ " " "W", que se referem também aos cônjuges dos germanos de mesmo sexo, e assim por diante.

Uma ciência do observador estaria plenamente autorizada a operar com as categorias de sua própria cultura e, com elas, construir uma rede genealógica, como fez Rivers, que procura "deixar claro" a seu informante, Kurka ou Arthur, que desejava saber "os nomes de seus pais biológicos e não de alguma outra pessoa que ele assim chamasse, devido ao sistema classificatório de relações” 
([1910] 1969: 28). De maneira análoga, um demógrafo, a fim de garantir a comparabilidade de populações distintas, constrói pirâmides com faixas etárias previamente definidas, sem levar em conta as diferentes concepções nativas sobre as fases da vida e as idades, definidas em cada cultura. Contudo, uma ciência social do observado não está autorizada a adotar o mesmo procedimento na construção de seu objeto, que deve conter o ponto de vista dos atores da rede.

Retomando o problema, como proceder em situações em que inexistem nas línguas dos observados os rótulos lexicais que coincidam exatamente com os do antropologuês ( $F, M, S, D, H, W)$ ? Seria apressado desistir da modelagem genealógica diante deste impasse. Voltemos à etnografia. Entre os Enawene-Nawe, um homem só é "F" de uma criança, isto é, só tem direito de transmitir a ela o seu clã, se "pagar peixe" (kuhase etoile) para seu sogro. Esta expressão resume um conjunto de obrigações econômicas e cerimoniais de um genro, que devem ser efetuadas antes, durante e depois do nascimento do bebê. Se tais obrigações não forem cumpridas, a criança permanecerá no clã do pai da mãe, independentemente da convicção dos observados acerca dos vínculos reprodutivos que a criança eventualmente mantém com um dado parceiro sexual da mulher que acaba de dar à luz. Além disso, o nascimento de uma criança desencadeia um longo período de resguardo (kadeena), que é observado apenas pela mulher de cujo ventre a criança saiu e não por todas aquelas que o bebê chamará de "mãe" quando aprender a falar.
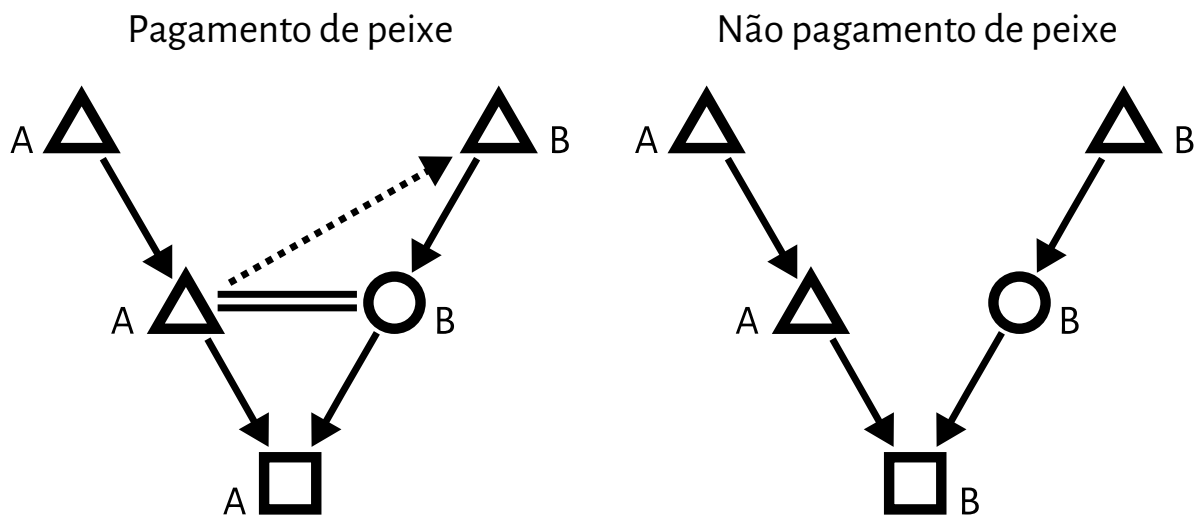

\section{Figura 5}

Casamento $\mathbf{=}$ vínculo reprodutivo $\rightarrow$ pagamento de peixe $\rightarrow$ e descendência $(\mathbf{A}, \mathbf{B})$

Nesta circunstância, todo marido tem expectativa de pagar peixe a seu sogro e o faz a fim de incorporar a criança a seu próprio clã. Nenhum outro "pai" (hahare) da criança o fará. Da mesma forma, nenhum outro "pai" observará os rigores do resguardo e nenhum homem estará socialmente autorizado ou moralmente obrigado a pagar peixe ao pai da mulher que acaba de dar à luz, ainda que classifique a criança como "filho(a)". Além disso, se, por um lado, a gestação e a trans- 
missão de substâncias são condições necessárias para o estabelecimento do vínculo de maternidade, por outro lado, são os nomes que a mãe adota, a partir dos nomes transmitidos à criança, que o legitimam. Em suma, entre os Enawene-Nawe, a transmissão de substâncias corporais é necessária para a definição dos laços de paternidade e maternidade, mas não suficiente. A parentalidade e a conjugalidade trazem para o primeiro plano, antes de tudo, trocas onomásticas pelas quais uma genealogia do observado pode ser modelada.

Por ocasião do nascimento, uma criança recebe um prenome $(X)$ de seu avô materno e outro $(Y)$ de seu avô paterno. Esses parentes e suas esposas passam a ser designados por tecnônimos como "avô" ou "avó de X ou Y". No caso de ter sido gerada fora do casamento, a criança recebe nome apenas de seu avô materno. Paralelamente, os pais passam a ser chamados de "pai ou mãe de X" ou "pai ou mãe de Y" pelos parentes maternos e paternos da criança, respectivamente. Com a efetuação do pagamento de peixe, o avô materno esquece/descarta (hotaka) o nome " $X$ " que deu à criança. Apenas o nome " $Y$ " transmitido pelo avô paterno se mantém e a criança é definitivamente incorporada a seu clã $\tilde{a}^{3}$. Paralelamente, apenas os tecnônimos formados pelo nome atribuído pelo avô paterno se consagram. Nos casos de crianças sem pai, o avô materno, por não receber peixe, jamais esquecerá o nome que transmitiu ao bebê, garantindo a permanência da criança em seu clã. Dessa forma, o método genealógico enawene-nawe subordina a filiação ao casamento e a descendência à aliança de casamento, condicionando o vínculo de paternidade e, consequentemente, $\mathrm{o}$ acesso ao patriclã ao pagamento de peixe ao sogro. Em suma, do serviço da noiva e dos dispositivos onomásticos nativos ou, parafraseando Schneider (1984: 196), de um pequeno conjunto de signos de que a cultura enawene-nawe consiste, emerge uma rede genealógica do observado. Neste caso, uma rede de relações de intercâmbios de afetos, comida, direitos, substâncias corporais, memórias, etc., e não de vínculos de transmissão de DNA.

Mas é preciso dar mais um passo. Tenhamos em mente outro pressuposto de uma modelagem genealógica propriamente antropológica para o estudo dos regimes empíricos de aliança. É preciso supor que os casamentos lá efetuados repousem sobre escolhas de alguma forma conscientes, que se manifestam como arranjos de perspectivas egocentradas e parciais da rede. A modelagem, contudo, produz um objeto sociocentrado. Por esta razão, algumas propriedades do regime de alianças, por ele reveladas, não necessariamente, encontram ecos no discurso do observado. Isto seria uma evidência contrária à possibilidade de uma rede genealógica propriamente antropológica? Certamente, não. Por que não a tomar como o célebre circuito global do Kula, que conecta as ilhas de um certo arquipélago da Melanésia? Aquele circuito (The Kula Ring), como todos se recordam, é invisível aos ol hos do melanésio de tal ou tal ilha que, apesar disso,
3 Não deixa de ser curioso o consumo de carne de peixe produzir o esquecimento, ao contrário do que acredita nosso senso comum. 
encontra-se incessantemente empenhado em sua construção.

Passemos a outro procedimento imprescindível da modelagem genealógica, a datação dos casamentos. "Datação" talvez não seja uma boa palavra, uma vez que o que importa definir não são propriamente datas, mas a posição relativa dos casamentos em um eixo temporal ${ }^{4}$. Não devemos perder de vista a premissa fundamental da análise das estruturas reticulares do parentesco, segundo a qual:

cada casamento é, em parte, condicionado pelos casamentos que o precedeme, por seu turno, contribui para determinação dos casamentos subsequentes. (...) $O$ peso de tal ou tal união anterior na determinação de tal ou tal união subsequente certamente pode ser dificil de precisar. Entretanto, o papel que representa a influência conjugada das alianças passadas na seleção de cônjuges futuros parece inegável (Houseman e White, 1996: 60).

Em suma, as redes de parentesco evoluem não só no espaço social, mas também no tempo e, nelas, os casamentos não ocorrem ao sabor do acaso, mas estariam de alguma forma relacionados uns aos outros. Houseman e White também chamam a atenção de que as análises etnográficas tradicionalmente conferem às práticas matrimoniais um lugar menor. Segundo os autores,

a abordagem estrutural da a liança de inspiração lévi-straussiana consiste, antes de tudo, na análise lógica de uma série de regras de casamento, positivas ou negativas (...) cuja aplicação repetida conduziria a uma regra com tais e tais propriedades. A verificação dessas propriedades a partir da consideração dos casamentos reais lá representa um procedimento acessório" (1996: 61).

Normalmente, em uma monografia, alguns poucos casamentos bastam como exemplos de aplicação de uma dada regra de casamento. Enquanto isso, o corpus genealógico da pesquisa etnográfica, onde figura o universo das formas matrimoniais a que a pesquisa teve acesso, costuma ter dois destinos. Na pior das hipóteses, permanece inédito para sempre. Na melhor, é despachado para um apêndice, raramente explorado, com diagramas de complicação impossível, para fazer eco à exclamação de Coldenweiser, diante do material Crow. Certamente, as monografias clássicas (e seus leitores) não podiam pensar outra coisa, já que, a olho nu, essas redes genealógicas são mesmo de complicação impossível. Mas agora, com auxílio de métodos informáticos com os quais, evidentemente, Goldenweiser não poderia nem sonhar, talvez sejam de complicação possível.

Houseman e White, em síntese, propõem trazer as redes empíricas para o centro da análise. Mas esses autores também se afastam das análises de redes egocentradas, debruçadas sobre alguns poucos exemplos de "estratégias pelas
4 Durante a pesquisa de campo, procedi à datação das uniões conjugais do corpus enawene-nawe com base em procedimentos muito simples: como o tempo de coabitação do casal, anterior ao nascimento do primeiro filho, varia consideravelmente, optei por estabelecer como data de casamento a data de nascimento do primeiro filho. Com isso, não foi difícil estabelecer as datas dos casamentos mais recentes. Com base nesses mesmos registros e em outros dados censitários produzidos nas décadas de setenta e oitenta, tabulei as diferenças etárias entre os cônjuges e as idades dos homens e mulheres quando pais ou mães pela primeira vez. Em seguida, calculei a idade média na primeira paridade, o número médio de filhos tidos e o intervalo médio entre nascimentos sucessivos, de 1955 a 1997. Com essas informações, estimei a data dos casamentos mais antigos, bem como as datas de nascimento e óbito dos ancestrais da população atual, que figuram na franja superior da rede. Os interessados nos aspectos demográficos dos Enawene-Nawe encontrarão mais informações em Silva (2016). 
quais os indivíduos exploram a rede de relações que os rodeia" (1996: 61). No lugar dessas alternativas, que oscilam, como um pêndulo durkheimiano, entre a regra social e a estratégia individual, os autores prescrevem um terceiro caminho, tornado possível com a incorporação de ferramentas computacionais: a observação da "rede ela mesma, enquanto totalidade produzida pela (e que preside a) interdependência de uma multidão de iniciativas particulares vinculadas entre si" (1996: 61). Esta é a aposta.

Esses e outros autores ${ }^{5}$ indicaram o caminho das pedras rumo ao estudo das práticas matrimoniais. A eles devemos o desenvolvimento vertiginoso da informatização dos estudos de parentesco, notadamente a partir da última década do século XX. Ninguém supõe, contudo, que máquinas sejam capazes de fazer milagres. Como Hamberger e Daillant sublinham com razão,

[u]m sistema de intercâmbio generalizado ou de casamento árabe se reconhece no campo, não atrás de um computador. O tratamento informático das redes de parentesco não serve para descobrir instituições; serve para compreendê-las, tornando visiveis e mensuráveis os efeitos que decorrem de suas interações (2008: 35).

Mas, se essas ferramentas não são varinhas de condão, por outro lado podem favorecer a retomada do projeto lévi-straussiano, com um novo fôlego. Precisamente por isso, devemos apostar nossas fichas não na Doutrina da Unidade Genealógica da Humanidade, que Schneider ironiza com razão, mas na outra Doutrina que por razões que me escapam o autor não enfrenta em sua crítica. Por esta razão, em homenagem a de Schneider-e por falta de rótulo melhor - denomino essa outra de Doutrina da Universalidade da Proibição do Incesto, que será retomada adiante.

Por fim, alguém poderia ponderar: admitamos que seja possível elaborar uma genealogia do observado. Mas esse não é o problema. Seu rendimento analítico compensaria os custos de sua construção? Qualquer etnólogo que já tenha se dedicado a esta tarefa sabe quanto tempo e esforço ela requer, mesmo em coletivos de proporções relativamente reduzidas. Esta questão é crucial e, nos limites deste texto, lamento não poder enfrentá-la apropriadamente. O que posso é trazer aqui alguns resultados preliminares de uma tentativa de abordagem do funcionamento real de um sistema de parentesco que, a meu ver, são promissores. Comecemos pelo princípio.

De uma perspectiva matemática, o modelo reduzido estabelecido pelo método de Rivers (1910) consiste em um grafo, constituído por um conjunto de vértices (indivíduos) e um conjunto de relações, que podem ser orientadas (arcos) como a filiação ou não orientadas (arestas) como o casamento. Os casamentos podem produzir ciclos na rede, que resultam quando os cônjuges são previa-
5 Ver especialmente, Fischer (1994)

6 Em sua crítica aos estudos de parentesco, Schneider concentra seus ataques à Doutrina da Unidade Genealógica da Humanidade. Lembrado apenas em duas discretas passagens, Lévi-Strauss, contudo, não sai ileso. Schneider pinça em sua obra duas afirmações comprometedoras. Em uma delas, Lévi-Strauss afirma que "a mitologia é um produto puro e desembaraçado da mente humana, de tal maneira que o parentesco não o é" (citado em Schneider, 1984: 141; grifo meu). Em outra passagem, diz que o "valor da troca não é simplesmente aquele dos bens trocados, uma vez que ele provê os meios de ligar os homens uns aos outros e de sobrepor aos laços naturais do parentesco os laços artificiais da aliança" (1984:173; grifo meu). Não obstante, Schneider lembra que Lévi-Strauss ([1945] 2003) diz também que um sistema de parentesco não consiste naqueles "laços objetivos de filiação ou consanguinidade dados entre os indivíduos", mas "existe apenas na consciência humana e constitui um sistema arbitrário de representações, não o desenvolvimento espontâneo de uma situação factual". Com base apenas nessas evidências, Schneider conclui: "Eu posso então estar errado em atribuir esta posição a Lévi-Strauss. Ou pode ser que Lévi-Strauss não seja inteiramente consistente" (1984: 141). 
mente ligados entre si por laços de consanguinidade e/ou afinidade (os matemáticos diriam, quando já existir um caminho na rede entre eles). Estes circuitos, na área de fronteira entre os estudos de parentesco e a computação, são denominados anéis matrimoniais (K. Hamberger et al., 2004: 86-7). Nos horizontes da aliança, o fenômeno pertinente em uma genealogia do observado é a rede produzida pelo entrelaçamento desses anéis, que são criados a cada novo casamento e que desaparecem com o esquecimento dos ancestrais e de suas relações. Como se percebe, apesar da aparência de novidade informática, os anéis na verdade são velhos conhecidos dos estudos de parentesco.

Em um texto anterior (Dalpoz e Silva, 2010), propusemos uma classificação dos anéis, baseada em seus elementos constitutivos. Os anéis são circuitos genealógicos formados por cadeias de relações de dois tipos: (A)finidade (casamento) e (C)onsanguinidade (filiação). Um anel $\mathrm{A}_{1} \mathrm{C}_{1}$ é um circuito composto por uma cadeia de filiação e um casamento; um $\mathrm{A}_{2} \mathrm{C} 2$, por dois casamentos e duas cadeias de filiação, e assim por diante. O número de casamentos em um anel sempre é igual ou maior que o número de cadeias de filiação ${ }^{7}$. Os vértices de um anel, conectados entre si por uma relação de casamento, são os indivíduos em posição de aliança deste anel (Dal Poz e Silva, 2009).

As relações, que ao longo do tempo, produzem um dado circuito matrimonial, são entes históricos cujo encadeamento nem sempre é evidente, se levarmos em conta apenas as informações genealógicas stricto sensu (filiação e casamento), senão vejamos. Seja um circuito matrimonial com dois casamentos. Este circuito pode ser representado de duas maneiras (1 e 2), como na Figura 6:

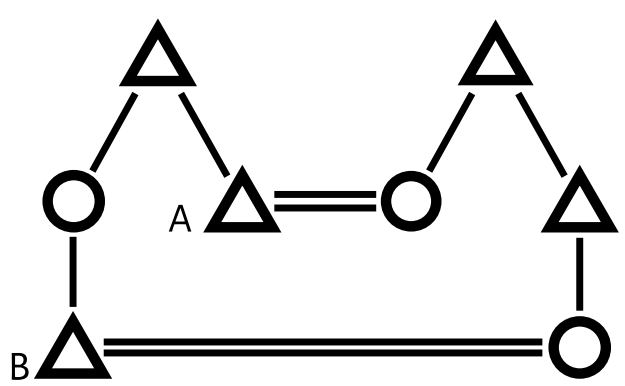

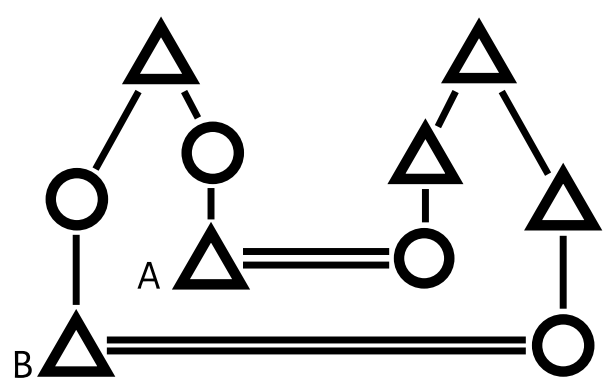

Figura 6

Duas representações de um mesmo anel ou de dois anéis diferentes.

As duas representações da Figura 6 são rigorosamente equivalentes, desde que uma delas seja lida em sentido horário e outra em sentido anti-horário. Mas são completamente diferentes se forem lidas no mesmo sentido, já que a da esquerda (1) sugere que o casamento do homem " $B$ " pode ter sido, em parte, condicionado pelo casamento do homem " $A$ ", enquanto o da direita (2) sugere o contrário. No anel da esquerda, um homem (B) se casa com sua MMSWFSD; no da direita, um homem (A) se casa com sua MDSWFFD. Como a seniori- 
dade genealógica de um parente colateral não necessariamente implica sua prioridade matrimonial, o casamento de um sobrinho (B) pode anteceder ao casamento de seu tio (A). Diante de uma figura circular como são os anéis, por onde então começar a analisá-la? Para que possa ser abordado, a ferramenta computacional deve retificá-la ${ }^{8}$, isto é, cortá-la, no casamento consequente (ou mais recente) ${ }^{9}$. Por convenção, um anel é iniciado por um dado indivíduo e fechado por seu cônjuge (Richard, 1993).

Observemos agora a Figura 7, em que o homem (1) está casado com a mulher (7). Este homem (1), por sua vez, é filho do homem (2), que é filho do homem (3), que tem outro filho (4), que tem um filho (5), que é casado com a mulher (8), que é filha da mulher (6), que tem outra filha (7), que é cônjuge do homem (1). O circuito aqui representado é um anel do tipo $\mathrm{A}_{2} \mathrm{C} 2$, uma vez que contém dois casamentos $(1=7$ e $8=5)$ e duas cadeias de filiação (1-2-3-4-5 e 7-6-8). Neste circuito, nota-se que o homem (1) não está casado com parente, pois, entre (1) e (7), não há um ancestral comum (junção, na linguagem da informática). Mas (1) está casado como um parente, no caso, como o seu primo (5), já que suas esposas (7) e (8) são, ambas, filhas de (6).

O censo matrimonial da rede enawene-nawe, efetuado com o emprego do aplicativo MaqPar, identificou 16 anéis $\mathrm{A}_{1} \mathrm{C}_{1}, 2 \mathrm{~A}_{2} \mathrm{C}_{1}$, 2.539 $\mathrm{A}_{2} \mathrm{C} 2, \varnothing \mathrm{A}_{3} \mathrm{C}_{2}$ e 144.387 $\mathrm{A}_{3} \mathrm{C}_{3}{ }^{10}$. O número de anéis matri-

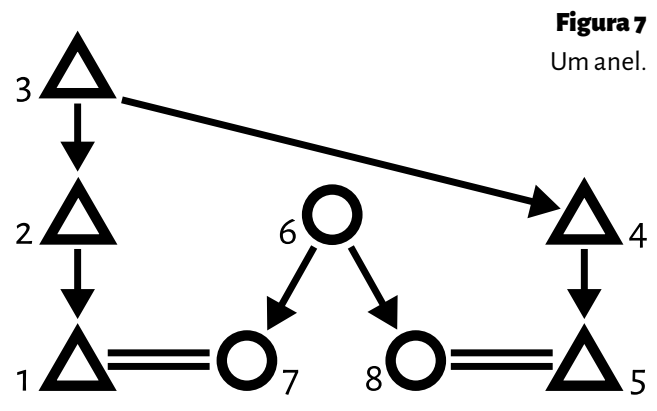
moniais de diferentes tipos em uma rede empírica tem sentido indicativo e não absoluto" ${ }^{11}$. Trata-se de um recurso impressionista para avaliar seu grau de densidade. Da relação entre o número de anéis e os números gerais de uma população (Silva, 2016), é possível entrever o grau de imbricação de seus nexos de parentesco. Por razões práticas, até o momento, procuramos em uma rede genealógica anéis com no máximo três casamentos, mas nada impediria a procura de anéis de profundidade maior. Neste universo, levamos em consideração apenas os circuitos minimais. Um anel minimal é um circuito que não contém outro circuito em seu interior.

Este ponto merece uma breve digressão. A distinção entre anéis minimais e não-minimais, proposta por White (2004), a meu ver é apenas relativa, pois depende das seleções efetuadas durante a modelagem de uma rede genealógica. Assim, por exemplo, segundo a modelagem padrão (Rivers, 1910), todo anel $\mathrm{A}_{1} \mathrm{C}_{1}$ é minimal. $\mathrm{O}$ mesmo não se passa com anéis maiores.
8 "Retificar um circuito matrimonial" significa transformá-lo em uma reta, em que o primeiro indivíduo está casado com o último.

9 Em um anel que contenha, por exemplo, o casamento de um indivíduo e o de seu bisneto, não haverá dificuldade em retificar o anel. Mas há situações etnográficas muito frequentes em que não há como decidir qual é o casamento antecedente e o casamento consequente, ainda que um seja anterior ao outro. É o caso de um circuito $\mathrm{A}_{2} \mathrm{C}_{2}$ produzido por troca de irmãs, por exemplo. Neste caso, duas retificações de um mesmo anel são necessárias.

10 O aplicativo MaqPar foi programado para encontrar anéis matrimoniais em coletivos de pequena escala (Dal Poz e Silva, 2009, 2010). Os interessados em testá-lo poderão encontrá-lo em linha, no endereço <http://maqpar. zip.net> "outros sites", com uso da senha de visitação "maqpar". A versão 2.7 foi elaborada na plataforma Microsoft Access (c). Neste mesmo endereço, encontra-se também um manual de instruções. Para a varredura de redes de grande complexidade, recomenda-se enfaticamente o emprego da nova versão da MaqPar (Ferreira; Franco e Silva, 2014), elaborada em software livre, em linha no endereço <http:// www.ime.usp.br/ alvaro/ maqpar/s.

11 O número de anéis em populações que, do ponto de vista demográfico, são praticamente idênticas pode variar muito. Um coletivo ameríndio com perfil populacional semelhante ao dos Enawene-Nawe, mas cuja cultura prescreva casamentos com parentes 
Com base na Figura 8, o casamento $1=6$ pode ser descrito de quatro maneiras diferentes: de um homem (a) com sua $\operatorname{MBD}(1,3,4,6)$, (b) com a sua FWBD $(1,2,3,4,6)$, (c) com a sua MBWD $(1,3,4,5,6)$ e com sua FWBWD $(1,2,3,4,5,6)$. A primeira descrição corresponde a um anel $\left(\mathrm{A}_{1} \mathrm{C}_{1}\right)$ minimal, a segunda e a terceira, a anéis ( $\left.A_{2} C_{2}\right)$ não minimais, porque contêm o anel $\mathrm{A}_{1} \mathrm{C}_{1}$. A quarta, descreve um anel $\left(\mathrm{A}_{3} \mathrm{C}_{3}\right)$ não minimal, pela mesma razão. Dumont ([1953] 1975), em sua elegante interpretação do problema da afinidade na Índia, opta pela segunda e não pela primeira. De acordo com o autor, só ela é capaz de captar o sentido do parentesco dos povos de línguas dravídicas. Mas Dumont não diz só isso. Diz também que a aliança, da perspectiva nativa, corresponde a uma relação entre pessoas do mesmo sexo, como no diagrama da Figura 9.

Se a afirmação de Dumont estiver correta, uma modelagem sensível ao ponto de vista nativo, deveria partir da postulação, para um único coletivo, não de uma
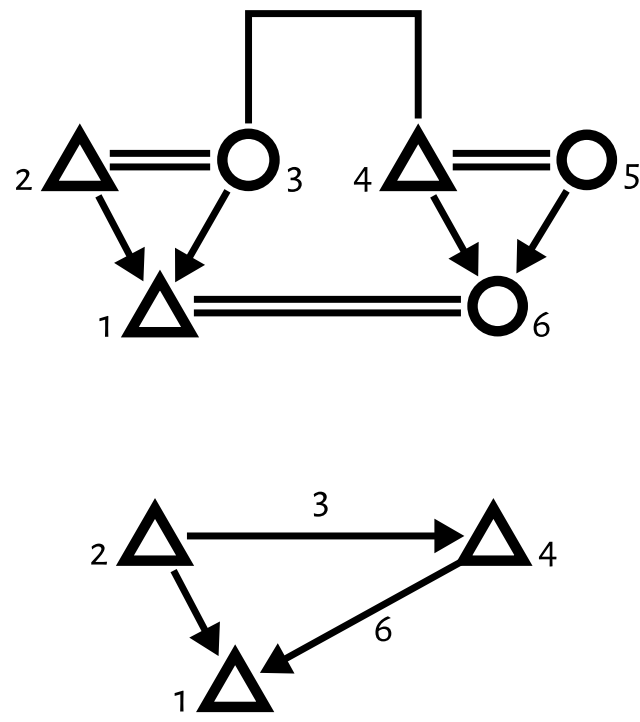

próximos (de primos cruzados ou de tio com sobrinha, por exemplo) ou favoreça matrimônios poligâmicos certamente apresentaria anéis matrimoniais em número bem maior. Inversamente, em um condomínio urbano de classe média, com o mesmo número de pessoas que a população enawene-nawe, o número de anéis poderia tender a zero.

\section{Figura 8}

Um anel minimal, segundo a notação convencional (Rivers, 1910).

\section{Figura 9}

O anel dravidiano, segundo Dumont (1953). única rede genealógica, mas de duas redes paralelas, levando-se em conta as diferentes perspectivas de cada sexo. Uma delas representaria os homens como termos (vértices) e as muIheres como relações (arestas). A outra faria o oposto. Esta nova modelagem genealógica (como o esquema na Figura 9), mais próxima da perspectiva nativa que a modelagem tradicional (riveriana), descreve o casamento ( $1=$ 6), como casamento com FWBD $e$ ao mesmo tempo como um grafo minimal.

Situações como essa preconizam a construção de métodos informáticos mais totais e menos universais, sensíveis às diferentes configurações culturais. Para nós, está claro que uma análise computacional do material multiforme de que consiste o parentesco em cada caso particular demanda o emprego de modelagens sob medida, capazes de integrar categorias, normas e práticas definidas em cada caso $^{12}$ e não de tratamentos unicamente voltados à automação do método de Rivers. Tais situações preconizam ainda uma apropriação intuitiva da ferramenta computacional, como sugerimos na conclusão deste artigo. Não há receitas informáticas prontas para o estudo do parentesco.

12 Este é, em resumo, o objetivo da pesquisa Dynamical Craphs in Anthropology, que desenvolvo em parceria com Carlos Eduardo Ferreira (do Instituto de Matemática e Estatística da USP), que integra o projeto "Storage, Modeling and Analysis of Dynamical Systems fore-Science Applications" (20162019), coordenado por João Eduardo Ferreira (IME-USP / FAPESP PT 15/01587-0) 


\section{OUTRAS PREMISSAS DA MODELAGEM COMPUTACIONAL DE UMA REDE DE PARENTESCO}

Retomando nossa miniatura do avião em um túnel de vento, convém insistir que qualquer tentativa de estudo de um fenômeno complexo como o parentesco (e que fenômenos antropológicos não o são?) deve, de início, nele isolar certas propriedades e certas relações que serão consideradas importantes e ignorar tudo o que sobra (e sempre sobrará muita coisa). Em outras palavras, a complexidade que caracteriza o objeto no mundo que designamos "parentesco" deve ser reduzida a fim de permitir sua abordagem computacional. Até hoje, a meu ver, Lévi-Strauss foi quem sugeriu a redução analítica mais promissora. Seguindo pistas muito conhecidas - os conceitos de reciprocidade, como condição de possibilidade da vida social e de troca, como seu nexo instituinte, elaborados por Mauss ([1923-1924] 1974) - o autor privilegia um aspecto central do parentesco, a aliança de casamento. Esta trilha não pode ser descartada.

Como bem assinalam Hamberger e Daillant, retomando Lévi-Strauss:

A análise dos casamentos é a chave da análise das redes de parentesco. Ainda que a filiação esteja longe de constituir um simples dado, definitivamente estabelecido no nascimento de um indivíduo, a a liança matrimonial corresponde ao lugar principal onde os humanos intervêm para moldar a rede de seus laços genealógi$\cos (2008: 13)$.

Os fenômenos cobertos pelo rótulo "parentesco" estão longe de compor uma matéria homogênea, dotada de organização interna e limites definidos. Ao contrário, o vocábulo reúne temas ecléticos, de diversas ordens de realidade. A fim de reduzir a complexidade do fenômeno observacional, os estudos de parentesco, ao longo de décadas, acabaram por abstrair três planos de observação e comparabilidade, categorias, normas e práticas. Em linhas gerais, o plano das categorias compreende as classificações que fornecem o suporte conceitual pelo qual um dado coletivo organiza suas relações de consanguinidade e afinidade, segmentando o continuum genealógico em unidades discretas. O plano das normas é aquele em que figuram ideias e valores que definem interdições e preferências matrimoniais, direitos e obrigações, padrões atitudinais, etc., que se manifestam em crenças, costumes e instituições, de alguma forma, implicadas no parentesco. Por fim, o plano das práticas é aquele voltado ao modo como os atores de um dado coletivo forjam efetivamente (e como podem) suas redes de parentesco, que evoluem, no espaço e no tempo social, em estado de turbulência permanente, para empregar um clichê.

Barnard e Cood (1984: 13), autores de um consagrado manual de rotinas de 
pesquisa voltadas ao parentesco, chamam a atenção de que categorias, normas e práticas, "uma vez que podem variar independentemente, precisam ser examinadas e analisadas independentemente". Este procedimento de descoberta é indispensável em uma primeira abordagem do corpus etnográfico, que a ele confere uma dada organização. Não obstante, ao longo da análise, categorias, normas e práticas devem ser examinadas e analisadas conjuntamente. Caso contrário, as conexões de sentido entre esses planos ficarão para sempre invisíveis. Trautmann (1981: 29), em seu tratado sobre os sistemas indianos, avança outro aspecto importante. Segundo o autor, a análise deve obedecer a uma ordem de certa forma imposta pelo próprio material, partindo do estudo das categorias, seguido do estudo das normas, até chegar ao estudo das práticas. Isto porque, pondera o autor, não há como entender as práticas sem se levar em conta as regras que lhe dão sentido, assim como não há como entender as regras sem a consideração das categorias com as quais tais normas são enunciadas pela cultura que as definem.

As cautelas metodológicas de Barnard, Cood e Trautmann não devem, contudo, ser confundidas com hipóteses sobre a organização interna do próprio objeto teórico. Nenhum desses planos deve ser tomado como termo determinante dos demais, mas como repercussões do termo subordinante do parentesco, a troca, condição necessária e suficiente para a sua definição. Precisamente por isso, categorias, regras e práticas podem definir fenômenos não necessariamente congruentes. Nesse sentido, em um artigo pioneiro, Lévi-Strauss ([1945] 2003: 54-5) sugere a noção de "integração dinâmica" quando, por exemplo, "o quadro de termos de parentesco não reflete exatamente o de atitudes familiais, e reciprocamente".

Como não poderia deixar de acontecer em uma disciplina com poucos consensos, o conceito de troca, como condição de parentesco, é hoje tão polêmico como sempre foi. Talvez por isso, meio século depois da publicação de As estruturas elementares..., Lévi-Strauss volta a defender o seu ponto, insistindo que a troca decorreria diretamente dos impedimentos matrimoniais, que se exprimem em toda parte. "No limite, um único [impedimento] é suficiente para que o mecanismo da troca se desencadeie fora da consciência dos sujeitos" (Lévi-Strauss, 2000: 714). Tal afirmação faz eco a outras, formuladas há mais tempo. Recordemos algumas delas.

[O] papel primordial da cultura está em garantir a existência do grupo como grupo e, portanto, em substituir, neste domínio, como em todos os outros, a organização ao acaso. A proibição do incesto constitui uma certa forma-que se manifesta sob diversas formas - de intervenção. Mas, antes de tudo, é intervenção, ou, mais exatamente ainda, éa Intervenção (Lévi-Strauss, [1949] 1967: 47). 
Como esta Intervenção, em letra maiúscula no original, se manifesta? Observemos que

todos esses sistemas complicados de distinções terminológicas, de interdições, de prescrições ou de preferências nada mais são do que processos destinados a repartir as famílias por campos rivais ou aliados, entre os quais poderá e deverá desenrolar-se o grande jogo do casamento (Lévi-Strauss, [1956] 1982: 87).

Ora, o grande jogo do casamento é precisamente o objeto que se pretende explorar na região de fronteira entre a antropologia e a computação.

Devemos também recordar que a função de uma terminologia de parentesco

é gerar possibilidades ou impossibilidades de matrimônios, quer diretamente entre pessoas que se tratam por certos termos, quer indiretamente entre as que se tratam por termos derivados, de acordo com regras determinadas, dos usados por seus ancestrais (Lévi-Strauss, [1966] 1969: 127).

Tais possibilidades ou impossibilidades não teriam repercussões nas redes empíricas? Certamente, sim. A troca não apenas funda e organiza o encadeamento de circuitos matrimoniais, mas também se manifesta nas próprias conexões mínimas (arcos e arestas) que constituem esses circuitos genealógicos, senão vejamos.

Gregory e Viveiros de Castro nos dão uma pista de como podemos começar a abordar as genealogias definidas pelos coletivos que estudamos. Gregory (1982: 19) define a troca de dons como transmissão "de coisas inalienáveis entre pessoas que estão em um estado de dependência recíproca". Como Viveiros de Castro chama atenção, esta também é "uma boa definição de parentesco, pura e simplesmente" (2009: 246). Segundo o autor, não só o casamento, por razões óbvias, mas a filiação "pode também ser concebida como um processo de transmissão de coisas inalienáveis - partes corporais e substâncias, classicamente, mas também memórias, narrativas, vínculos territoriais - que criam pessoas que por isso permanecem em estado de dependência recíproca" (2009: 246).

Dessa perspectiva, um esquema genealógico pode ser tomado como um exercício de modelagem do entrelaçamento de cadeias de intercâmbios de signos e valores por meio de pessoas que estão vinculadas por trocas matrimoniais e filiativas, definidas em um dado coletivo. Precisamente é isso, como vimos, que o caso enawene-nawe traz à tona. 


\section{CONCLUSÃO}

Tentativamente, podemos abordar uma genealogia de muitas maneiras. Uma delas, intuitiva, é tomá-la como um grafismo, diante do qual o observador tem uma expectativa de sentido, que só será apreendido quando seu olhar der forma ao objeto em questão. Isto é, quando configurá-lo de uma determinada maneira. Como um grafismo, uma genealogia não é diferente do célebre desenho de Edgar Rubin, da taça e dois rostos, que tanto inspirou o movimento da Cestalt. Aquele desenho deixa evidente que, para ver taça ou dois rostos, a percepção tem antes que decidir o que é forma e fundo. Ambas as percepções do desenho são válidas, mas não é possível fazê-las simultaneamente.
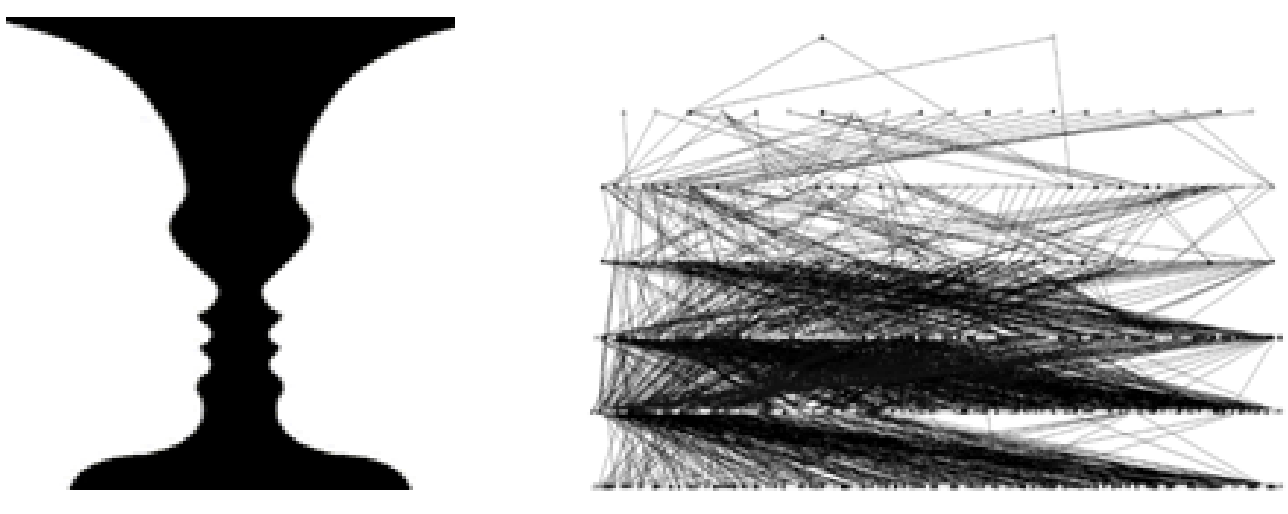

Diante da rede genealógica enawene-nawe é possível fazer o mesmo. Sua forma é composta pela imbricação de linhas de dois tipos, arcos e arestas (filiação e casamento, respectivamente). Seus nós (vértices) correspondem a duas formas geométricas distintas, círculos e triângulos, que representam a diferença sexual. Como na obra de Rubin, diante deste desenho, o olhar pode configurar seus entes trazendo para frente os acontecimentos matrimoniais que produzem os casais, dando forma a uma rede que surge sobre um fundo constituído por cadeias de filiação ou privilegiar as cadeias de filiação, que estabelecem relações de intercâmbio, dando forma a uma rede que emerge sobre um fundo constituído por casamentos. Convém assinalar, de passagem, que, na rede em questão, cadeias de filiação não correspondem aos clãs empiricamente dados, mas a acontecimentos filiativos, que repercutem os esquemas de nominação sobre os quais já me referi.

Como no desenho de Rubin, em que as percepções da taça e dos dois rostos são igualmente possíveis, com a condição de não se produzirem simultaneamente, as duas configurações da genealogia aqui propostas emergem como possibilidades de recorte, sob a mesma condição. A ilusão perceptual, tanto no 
desenho de Rubin quanto na rede genealógica, decorre do fato das cores preta ou branca da taça ou dois rostos, em um caso, ou das relações de filiação ou casamento no outro, fazerem fronteira uma com a outra. Além disso, as duas cores do desenho de Rubin, preta e branca, estão para as conexões da rede (filiação e casamento) assim como suas formas (taça ou dois rostos) estão para as duas formas do parentesco, consanguinidade e afinidade.

Abusando um pouco mais da metáfora, é preciso admitir que, se por um lado, é impossível ver ao mesmo tempo as figuras da taça e dos dois rostos, por outro lado é evidente que foram concebidas e produzidas ao mesmo tempo, não só pela razão trivial de que é impossível desenhar uma sem desenhar também a outra, mas também porque Rubin não desenhou apenas duas formas. $O$ prazer estético proporcionado pelo artista é precisamente a ilusão produzida, que não está em nenhuma das duas formas, tomadas isoladamente. Rubin não desenhou uma taça e dois rostos, mas o e feito da simultaneidade entre esses entes. O mesmo faz o artista das redes de parentesco, um dado "conjunto complexo de crenças, de costumes, de estipulações e de instituições que se designa sumariamente sob o nome de proibição do incesto" (Lévi-Strauss [1949] 1967: 10). Sua arte, neste caso, consiste em presidir o grande jogo do casamento, isto é, a "interdependência de uma multidão de iniciativas [matrimoniais] particulares religadas umas às outras" (Houseman e White, 1996: 61).

A dupla possibilidade de configuração do grafismo genealógico, que ora dá forma aos acontecimentos matrimoniais, ora aos acontecimentos filiativos de uma dada rede, permite distinguir, respectivamente, as noções aliancistas de redobramento (Héritier, 1981) e reencadeamento (Segalen, 1985; Richard, 1993). Mas esta distinção não basta. O passo seguinte é esclarecer o que significa exatamente, em termos computacionais, configurar o olhar diante de uma rede genealógica. Como hipótese de trabalho, podemos supor que redobramentos ou reencadeamentos correspondem a partições distintas do grafo, que selecionam, em cada caso, um dado subconjunto de anéis, invisível a olho nu.

Com o emprego de ferramentas computacionais, podemos dar forma aos acontecimentos matrimoniais de uma rede, levando-se em conta o modelo analítico de Héritier (1981), fundado na variação de parâmetros de repetição de aliança de consanguíneo próximo, segundo o sexo. O passo seguinte é rastrear todos os anéis minimais $\mathrm{A} 2 \mathrm{C} 2$ da rede e, para cada indivíduo em posição de aliança de um dado anel, determinar se o seu casamento redobra ou não a aliança estabelecida por um consanguíneo seu. Na rede enawene-nawe, de um total de 170 casamentos registrados na genealogia, apenas 96 oferecem condições de teste para esse exercício. Neste universo, 63,5\% podem ser interpretados como redobramentos de aliança de consanguíneos próximos (61 casos).

Assinale-se de passagem que uma pessoa, ao se casar, pode realizar mais 
de um redobramento (gerar mais de um anel na rede), o que comumente acontece. Existem 201 anéis de redobramentos de aliança envolvidos nesses 61 casamentos, dos quais 126 (63\%) são de parentes do sexo oposto, 75 (37\%) do mesmo sexo e 28 (14\%) de ambos os sexos. O número médio de redobramentos por casal é 3 (máximo de 10, mínimo de 1). Do total de redobramentos, $52 \%$ são efetuados por esposas e $48 \%$ por maridos. Para ambos os sexos, o redobramento de aliança de parente de sexo oposto é duas vezes mais frequente que aquele entre parentes do mesmo sexo: respectivamente, $62 \% \mathrm{e}$ $38 \%$, para os homens, $63 \%$ e $37 \%$, para as mulheres. Esta desproporção caminha na direção do que Héritier (1981: 74-7) propõe como caracterização de um sistema semicomplexo.

Para dar forma às cadeias de filiação, podemos tentativamente rastrear os anéis com três conexões de casamento e três cadeias consanguíneas, com a condição de que o par de indivíduos em posição de aliança de cada cadeia seja formado por pessoas de um mesmo clã. Foram encontrados 370 anéis deste tipo na rede enawene-nawe, que permitem descrever 59 casamentos como reencadeamento de aliança de afim. Contudo, é importante assinalar que, muito comumente, um único casamento pode ao mesmo tempo estar envolvido em anéis de dois tipos, redobramento e reencadeamento. $O$ efeito da simultaneidade das duas figuras permite interpretar, na rede enawene-nawe, nada menos que $81,3 \%$ dos casamentos como redobramentos de aliança de consanguíneo, como reencadeamentos de aliança de afins ou como ambas as coisas.

O enfrentamento do desafio antropológico e computacional em área de fronteira aqui proposto está apenas no início. A modelagem e as duas partições da rede aqui sugeridas não pretende esgotar as possibilidades de análise da rede de parentesco em questão. Ainda assim, o exercício etnográfico tornou possível entrever o funcionamento real de um regime matrimonial que, à primeira vista, lembra uma charada, já que os Enawene-Nawe se pensam como um coletivo em que todos são parentes, ninguém se casa com parente, mas todos se casam entre si. Com base na tipologia estruturalista, podemos refrasear a charada, afirmando que os Enawene-Nawe operam, de direito, um regime de alianças complexo, mas, de fato, um regime elementar de troca restrita, que tende a uma estrutura semicomplexa, invisível a olho nu.

Marcio Silva é Professor Titular do Departamento de Antropologia, da Faculdade de Filosofia, Letras e Ciências Humanas, da Universidade de São Paulo. 


\section{REFERÊNCIAS BIBLIOGRÁFICAS}

BARNARD, A. e GOOD, A.

1984 Research Practices in the Study of Kinship. ASA Research Methods in Social Anthropology, n. 2. Londres, Academic Press.

DAL POZ, J. e SILVA, $M$

2009 "MaqPar-A Homemade Tool for the Study of Kinship Networks". VIBRANT. Vol. 6 (2): 29-51.

2010 "Informatizando o Método Cenealógico: um guia de referência para a Máquina de Parentesco". Teoria e Cultura, v.3: 63-78.

DUMONT, L.

[1953] 1975 "Le Vocabulaire de parenté dravidien comme expression du marriage". In Dravidien et Kariera: L'Alliance de marriage dans l'Inde du Sud et en Australie. Paris, Mouton: 85-100.

FERREIRA, C. E.; FRANCO, A. J. P. e SILVA, M.

2014 "Finding Matrimonial Circuits in some Amerindian Kinship Networks: An Experimental Study". Proceedings of The 2014 IEEE 10th International Conference on eScience: 73-80. Disponível em: http:// ieeexplore.ieee.org/xpl/articleDetails.jsp?arnumber=6972251

FISCHER, M.

1994 Application in Computing for Social Anthropology. ASA Research Methods in Social Anthropology. Londres, Routledge.

COOD, A.

1996 "Kinship". In BARNARD, A. e Spencer, J. (orgs.). Encyclopedia of Social and Cultural Anthropology. Londres, Routledge, pp. 311-317.

GREGORY, C.

1982 Gifts and Commodities. Londres, Academic Press.

FOX, R.

1967 Kinship and Marriage. Baltimore, Penguin Books. 
HAMBERGER, K. e DAILLANT, I.

2008 "L'Analyse de réseaux de parenté: concepts et outils".

Annales de Démographie Historique, (2): 13-52.

HAMBERGER, K. et al.

2004 "Matrimonial Ring Structures". Mathématiques, informatique et sciences humaires, 42(4): 83-119.

HÉRITIER, F.

1981 L'Exercice de la parenté. Paris, Gallimard/Le Seuil. Coll. Hautes Études.

HOLY, L.

1996 Anthropological Perspective on Kinship. Londres, Pluto Press.

HOUSEMAN, M. e WHITE, D.

1996 "Structures réticulaires de la pratique matrimoniale". L'Homme 139: 59-85.

1998 "Taking Sides: Marriage Networks and Dravidian Kinship in Lowland South America". In CODELIER, M., TRAUTMANN,

T. e TJON SIE FAT, F. (orgs.). Transformations of Kinship.

Washington, Smithsonian Institution Press, pp. 215-243.

JAKOBSON, R.

[1956] 1995 "Dois aspectos da linguagem e dois tipos de afasia".

In Lingüística e Comunicação. São Paulo, Cultrix.

[1959] 1995 "Aspectos linguísticos da tradução". In

Lingüística e Comunicação. São Paulo, Cultrix.

LÉVI-STRAUSS, C.

[1945] 2003 "A análise estrutural em lingüística e antropologia". In

Antropologia Estrutural. Rio de Janeiro, Tempo Brasileiro.

[1954] 2003 "Lugar da antropologia nas ciências sociais

e problemas colocados por seu ensino". Antropologia

Estrutural. Rio de Janeiro, Tempo Brasileiro.

[1956] 1983 "La Famille". In Le Regard éloigné. Paris, Plon.

[1949] 1976 As estruturas elementares do parentesco. Petrópolis, Vozes.

[1966] 1969 "O futuro dos estudos de parentesco". In LARAIA, R. de B. (org.). Organização social. Rio de Janeiro, Zahar Editores, pp. 124-144.

2000 "Postface". L'Homme, 154-155: 713-720. 
LOUNSBURY, F. G.

1964 "The Structural Analysis of Kinship Semantics". In LUNT, $\mathrm{H}$. (org.). Proceedings of The Ninth International Congress of Linguistics. Cambridge, The Hague, Mouton, pp. 1073-1093.

MAUSS, $M$.

[1923-1924] 1974 "Ensaio sobre a dádiva: forma e razão da troca nas sociedades arcaicas". In Sociologia e antropologia. São Paulo, EPU/EDUSP. Vol. II.

MCKINLEY, R.

2001 "The Philosophy of Kinship: A Reply to Schneider's Critique of the Study of Kinship". In FEINBERG, R. e OTTENHEIMER, M. (orgs.). The Cultural Analysis of Kinship: The Legacy of David M. Schneider. Champaign, University of Illinois Press, pp. 131-167.

MURDOCK, G.P.

1949 Social Structure. Nova York, Macmillan.

PORQUERES I GENÉ, E.

2008 Cenealogía y Antropología: los avatares de uma técnica de estúdio. Buenos Aires, Editores del Puerto / Centro Franco-Argentino de Altos Estudios, Universidad de Buenos Aires.

RICHARD, Ph.

1993 "Étude des renchaînements d'alliance". Mathématiques et Sciences Humaines, n. 123: 3-35.

RIVERS, W. H. R.

1910 "The Cenealogical Method of Anthropology Inquiry". Sociological Review, 3: 1-12.

SCHNEIDER, D.

1972 "What is Kinship All About?". In REINING, P. (org.). Kinship Studies in the Morgan Centennial Year. Washington, Anthropological Society of Washington.

1984 A Critique of the Study of kinship. Ann Arbor, The University of Michigan Press. 
SEGALEN, $M$.

1985 Quinze générations de Bas-Bretons. Parenté et société das le pays

bigouden sud 1720-1980. Paris, Presses Universitaires de France.

SILVA, M.

1998 "Tempo e espaço entre os Enawene-Nawe".

Revista de Antropologia, v.41: 21-52.

2008 "A aliança em questão: observações sobre um caso sul-americano".

In QUEIROZ, R.C. e NOBRE, R.F. (orgs.). Lévi-Strauss: leituras

brasileiras. Belo Horizonte, Humanitas/EDUFMG, pp. 301-324.

2012 Liga dos Enawene-Nawe: um estudo da aliança de casamento na Amazônia Meridional. São Paulo, Tese de Livre Docência, Faculdade de Filosofia, Letras e Ciências Humanas da Universidade de São Paulo.

2013 "Dinâmicas da vicinalidade entre os Enawene-Nawe". In AMOROSO, M. e SANTOS, G. M. (orgs.). Paisagens Amerindias. São Paulo, Ed. Terceiro Nome, pp. 17-44.

2016 "Demografia e antropologia em contraponto: os EnaweneNawe e suas derivas matrimoniais". Revista Brasileira de Estudos de População, v. 33, n. 2: 349-373.

TRAUTMANN, T. R.

1981 Dravidian kinship. Cambridge, Cambridge University Press.

TRAUTMANN, T. R. e BARNES, R. H.

1998 'DDravidian', 'Iroquois', and 'Crow-Omaha' in North American Perspective". In CODELIER, Maurice; TRAUTMANN, Thomas R. e TJON SIE FAT, Franklin E. (orgs.). Transformation of Kinship. Washington e Londres, Smithsonian Institution Press.

\section{VIVEIROS DE CASTRO, E.}

2009 "The Gift and the Given: Three Nano-essays on Kinship and Magic". In BAMFORD, S. e LEACH, J. (orgs.). Kinship and Beyond: The Cenealogical Model Reconsidered. Oxford, Berghahn Books, pp. 237-268.

WHITE, D.

2004 "Ring Cohesion Theory in Marriage and Social Networks". Informatique, Mathématique et Sciences Humaines, 168 (4): 59-82. 


\section{ABSTRACT}

According to Schneider (1984: 4, 119-120), anthropological studies of kinship are anchored in a Doctrine of the Cenealogical Unity of Mankind which has distorted ethnographic perception and consecrated a non-subject. This Doctrine can be summarized as follows: in all human cultures kinship concerns the acknowledgement of natural ties among individuals, thus warranting its universal translation in genealogical terms. This article counters Schneider's criticism on two fronts: inquiring if the genealogical method should necessarily be understood as a means of translation; and challenging whether the definition of the genealogical method requires such a Doctrine in the first place. In parallel, drawing considerations from ethnographic research concerning the Enawene-Nawe, this article, within the horizon of the alliance theory, argues in favor of the rehabilitation of the genealogical method, which in the present century cannot dismiss computational tools. This, considering that "the first task of anthropology, prerequisite to all others, is to understand and formulate the symbols and meanings and their configuration, that a particular culture consists of" (Schneider 1984: 196, emphasis in the original).

\section{KEYWORDS}

Kinship, Cenealogical Method, Translation and Models,

Alliance Theory,

Enawene-Nawe. 